\title{
Child with Wyburn-Mason syndrome presenting with sudden onset of intracranial haemorrhage
}

\author{
Karthik Shyam ำ, Dhilip Andrew ำ , Jovis Johny
}

Department of Radiology, St John's Medical College Hospital, Bangalore, India

\section{Correspondence to} Dr Karthik Shyam;

dr.karthikshyam@gmail.com

Accepted 14 June 2020

\section{DESCRIPTION}

A 10-year-old child presented to the paediatric emergency department with a history of two episodes of generalised seizure lasting 2-3 min each in the past 24 hours. Prior to seizure episodes, the patient had history of headache for 1 day and two episodes of projectile non-bilious vomiting. No other significant systemic complaints or history. The patient had normal developmental history and was immunised up to date. On general examination, the vitals were pulse: $78 \mathrm{bpm}$, respiratory rate: 22 breaths/min and blood pressure: $104 / 60 \mathrm{~mm} \mathrm{Hg}$; the patient had a low Glasgow Coma Scale (GCS) of 9/15 (E2M5V2) with

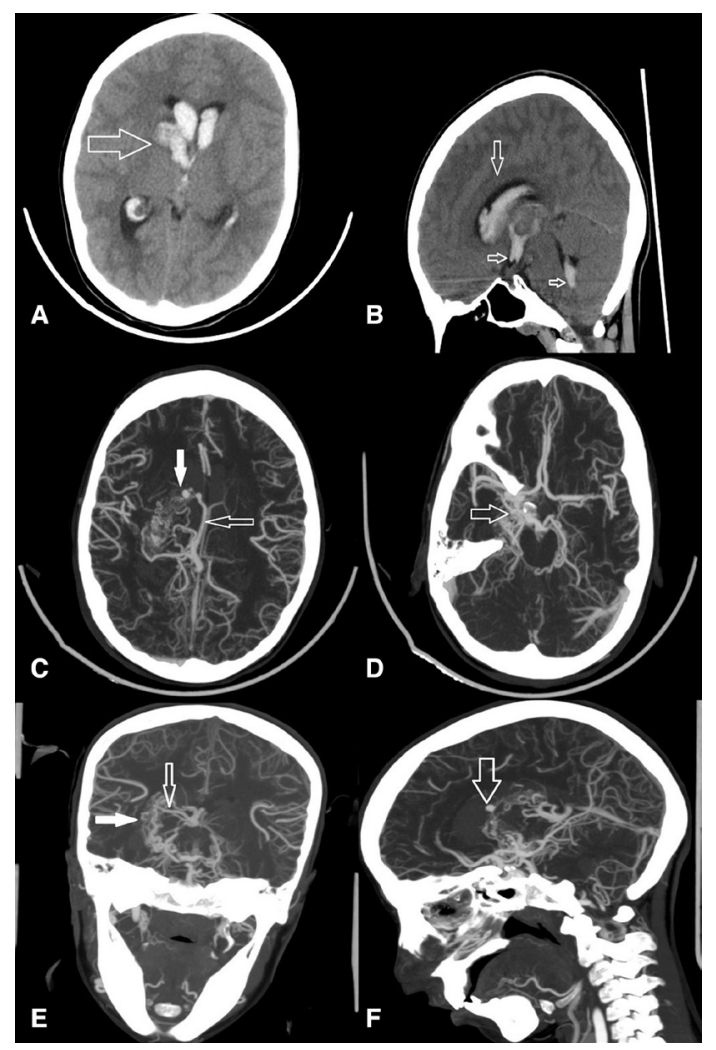

Figure 1 (A, B) Non-contrast CT of the brain demonstrating right gangliocapsular bleed with intraventricular extension (white arrows). (C, D) Axial CT angiogram images demonstrating arteriovenous malformations (AVMs) with aneurysm of draining vein (solid arrow), dilated internal cerebral vein and feeding vessel from right Posterior Cerebral Artery (white arrows). (E) Coronal CT angiogram section demonstrating AVMs (solid arrow) with draining vein (white arrow). (F) Sagittal $\mathrm{CT}$ angiogram image demonstrating aneurysm of the draining vein (white arrow).

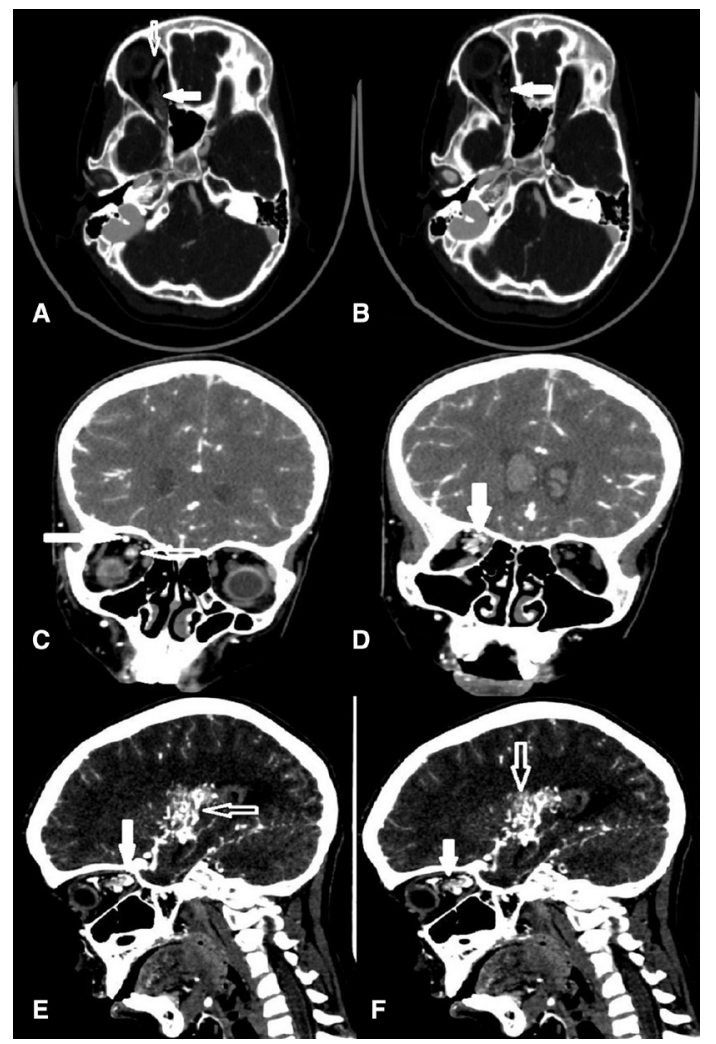

Figure 2 ( $A, B)$ Axial $C T$ angiogram demonstrating dilated superior ophthalmic vein (white arrow) and arteriovenous malformations (AVMs) adjacent to the optic nerve (solid arrow). (C, D) Coronal CT angiogram section demonstrates multiple AVMs (Solid arrow) adjacent to the optic nerve (White arrow). (E, F) Sagittal CT angiogram images demonstrating multiple AVMs adjacent to optic nerve (solid arrow) and intracranial AVMs (white arrow).

unequal pupils, which showed sluggish reactivity. On Central Nervous System (CNS) examination, the patient had brisk bilateral lower limb reflexes with normal tone, rest of the examination could not be performed due to low GCS. Rest of the systemic examination was normal. The routine blood investigations were within normal limits.

Non-contrast CT of the brain revealed foci of parenchymal haemorrhage in right gangliocapsular region with perifocal oedema (figure 1A,B). The patient underwent CT angiography, which revealed intracranial and orbital arteriovenous malformations (AVMs) (figure 1C-F). The intracranial malformation was in the right gangliocapsular region with feeding vessels arising from right Posterior Cerebral Artery (PCA) and draining into 
internal cerebral vein, two aneurysms were present in the draining vein. The right orbit showed features of AVMs in the retrobulbar region and along the optic nerve (figure 2A-F). Because of intracranial and orbital AVMs, the patient was diagnosed with Wyburn-Mason syndrome. On fundoscopic examination, multiple retinal angiomas were noted in the right eye.

Wyburn-Mason syndrome is a rare type of phakomatoses caused by developmental abnormality affecting primitive vascular mesoderm shared by the developing optic cup and anterior neural tube. The condition presents with unilateral vascular abnormalities involving the facial structure, orbits and brain; bilateral involvement has also been reported. ${ }^{1-3}$ These patients express an anomalous vessel consisting of arteries and veins with no capillary bed causing direct communication between the two. ${ }^{4}$ The patient can present with visual symptoms like monocular amblyopia, esotropia or both. ${ }^{5}$ The extent of the visual symptoms depends on the size, extent and location of the retinal AVM; they can even present with vision loss due to vitreous, intraretinal or macular haemorrhage, and neovascular glaucoma. ${ }^{6}$ The neurological manifestations of Wyburn-Mason syndrome are hemiparesis and haemorrhage; it is different from neurological manifestation of cerebral AVM, which presents with epilepsy. ${ }^{57}$ Cutaneous manifestation is seen in a minority of patients, which present as angiomas of the face, cheek, nose, mandible, palate, pharynx, maxilla and buccal mucosa. ${ }^{5}$

Patients are usually conservatively managed with close observation for changes in lesion size; surgical intervention has been successful for small AVMs and symptomatic haemorrhage. ${ }^{89}$ Surgical intervention of suprasellar AVM is frequently associated with visual loss. ${ }^{4}$ Non-surgical interventions are radiotherapy and embolisation. Radiotherapy is associated with

Learning points

- Wyburn-Mason syndrome presents with neurological, ophthalmic and cutaneous manifestations. Patients can present with either visual or neurological symptoms at initial presentation.

- Intracranial arteriovenous malformations (AVMs) are relatively stable, and embolisation is indicated in patients with intracranial haemorrhage.

- Any patient with retinal AVM should undergo neurological evaluation. endocrine abnormalities affecting the hypothalamic-pituitary axis and embolisation is used for cases that present with haemorrhage and not used prophylactically since the AVMs are relatively stable. ${ }^{10-12}$ Complete neurological evaluation with MRI of the brain should be considered in cases with retinal AVMs.

Contributors All three authors have equally participated in the collection of data and images, the compilation/editing of the subsequent report. DAMAR was responsible for the initial image interpretation, with inputs from KS and JJ. Patient clinical and laboratory details were obtained by DAMAR and KS. Images were obtained from the in-hospital PACS (Picture archiving and communication system) with due permission from the Head of Department, Radiodiagnosis and Imaging.

Funding The authors have not declared a specific grant for this research from any funding agency in the public, commercial or not-for-profit sectors.

Competing interests None declared.

Patient consent for publication Obtained.

Provenance and peer review Not commissioned; externally peer reviewed.

\section{ORCID iDs}

Karthik Shyam http://orcid.org/0000-0003-0998-9604

Dhilip Andrew http://orcid.org/0000-0002-6154-3063

\section{REFERENCES}

$1 \mathrm{Kim}$ J, Kim $\mathrm{OH}$, Suh JH, et al. Wyburn-Mason syndrome: an unusual presentation of bilateral orbital and unilateral brain arteriovenous malformations. Pediatr Radiol 1998;28:161-2.

2 Brodsky MC, Hoyt WF. Spontaneous involution of retinal and intracranial arteriovenous malformation in Bonnet-Dechaume-Blanc syndrome. Br J Ophthalmol 2002;86:360-1.

3 The Wyburn-Mason syndrome. Concomitant chiasmal and fundus vascular malformations. - Abstract - Europe PMC. Available: https://europepmc.org/article/med/ 6222080 [Accessed 26 May 2020 May 2].

4 Ponce FA, Han PP, Spetzler RF, et al. Associated arteriovenous malformation of the orbit and brain: a case of Wyburn-Mason syndrome without retinal involvement. Case report. J Neurosurg 2001;95:346-9.

5 Théron J, Newton TH, Hoyt WF. Unilateral retinocephalic vascular malformations. Neuroradiology 1974;7:185-96.

6 Goh D, Malik NN, Gilvarry A. Retinal racemose haemangioma directly communicating with a intramuscular facial cavernous haemangioma. Br J Ophthalmol 2004:88:840-2.

7 Mackenzie I. The clinical presentation of the cerebral angioma; a review of 50 cases. Brain 1953;76:184-214

8 Muthukumar N, Sundaralingam MP. Retinocephalic vascular malformation: case report. Br J Neurosurg 1998:12:458-60.

9 Lester J, Ruano-Calderón LA, González-Olhovich I. Wyburn-Mason syndrome. J Neuroimaging 2005;15:284-5.

10 Hypothalamic dysfunction following whole-brain irradiation in: Journal of neurosurgery, 1986. Available: https://thejns.org/view/journals/j-neurosurg/65/4/ article-p490.xml [Accessed 28 May 2020 May 2].

11 Duffner PK, Cohen ME, Voorhess ML, et al. Long-Term effects of cranial irradiation on endocrine function in children with brain tumors. A prospective study. Cancer 1985;56:2189-93.

12 de Keizer RJ, van Dalen JT, Dalen J. Wyburn-Mason syndrome subcutaneous angioma extirpation after preliminary embolisation. Doc Ophthalmol 1981;50:263-73.

Copyright 2020 BMJ Publishing Group. All rights reserved. For permission to reuse any of this content visit

https://www.bmj.com/company/products-services/rights-and-licensing/permissions/

BMJ Case Report Fellows may re-use this article for personal use and teaching without any further permission.

Become a Fellow of BMJ Case Reports today and you can:

- Submit as many cases as you like

- Enjoy fast sympathetic peer review and rapid publication of accepted articles

- Access all the published articles

- Re-use any of the published material for personal use and teaching without further permission

Customer Service

If you have any further queries about your subscription, please contact our customer services team on +44 (0) 2071111105 or via email at support@bmj.com.

Visit casereports.bmj.com for more articles like this and to become a Fellow 